\title{
Література:
}

1. Бояцис Р., Макки Э. Резонансное лидерство: самосовершенствование и построение плодотворных взаимоотношений с людьми на основе активного сознания, оптимизма и эмпатии : пер. с англ. Москва : Альпина Бизнес Букс, 2007. 300 с.

2. Вайсбах Х., Дакс У. Эмоциональный интеллект. Москва : ЛикПресс, 1998. 247 с.

3. Гоулман Д., Бояцис Р., Макки Э. Эмоциональное лидерство: искусство управления людьми на основе эмоционального интеллекта : пер. с англ.; 3-е изд. Москва : Альпина Бизнес Букс, 2008. 301 с.

4. Нестуля С. І., Нестуля О. О. Основи лідерства. Наукові концепції (середина XX - початок XXI ст.) : навч. посіб. Полтава : ПУЕТ, 2016. $375 \mathrm{c}$.

DOI https://doi.org/10.30525/978-9934-588-80-8-1.60

\section{FORMATION OF PROFESSIONAL SKILLS OF THE FUTURE TEACHER IN HIGHER EDUCATION INSTITUTIONS DURING THE STUDY OF THE DISCIPLINE «PEDAGOGY OF ART»}

\author{
Nozdrova O. P. \\ Candidate of Pedagogical Sciences, \\ Senior Lecturer at the Department of Pedagogy \\ South Ukrainian National Pedagogical University \\ named after K. D. Ushynsky \\ Bartienieva I. O. \\ Candidate of Pedagogical Sciences, \\ Senior Lecturer at the Department of Pedagogy \\ South Ukrainian National Pedagogical University \\ named after K. D. Ushynsky \\ Odessa, Ukraine
}

The current state of socio-political, economic instability in society creates problems of socio-economic, psychological and pedagogical, professional nature in the field of art education. This situation creates psychological and economic barriers that limit the methodological provison of the artistic process, as well as reduce the level of qualification competence of the future teacher, namely the use of innovative technologies and 
techniques for the use of theatricalizing, folk music, dance in the creative activities of future teachers [3, p. 24].

The relevance of this study is due to the fact that modern society places qualitatively new requirements for the professional skills of future teachers, namely: focus on the active search for the latest methods, tools, techniques, technologies of art education; influence on the development of creative abilities of the individual.

A sufficient number of works is devoted to the study of professional skills of the future teacher by means of musical-choreographic, theatrical art (L. Kurbas, R. Tovstonogov, A. Efros, I. Nalyvayko). Regarding the solution of general problems of philosophy of education, understanding the specifics of art education are important for our study are monographs, which address the generalization and systematization of problems of national education in general and art education in particular [2, p. 65].

The works of O. Yeremenko, I. Zyazyun, O. Lobova, S. Nychkalo, O. Ogienko, O. Rudnytska have an interdisciplinary character, as they cover the problems of philosophy of education, didactic and methodological problems of art education development [4, p. 240].

An important component in this context is the study of introduction of the discipline «Pedagogy of Art» in the educational process for students obtaining higher education at the first (bachelor's) level of pedagogical specialties.

The purpose of the discipline «Pedagogy of Art» - to give students an idea of the content and features of the professional activities of specialists in music and choreographic education, the main trends in the creative personality of the future teacher of art disciplines; acquaintance with the structure and content, methodological principles of art education, with the essence of pedagogical skill, its levels of formation; awareness of the didactic principles of the learning process in the disciplines of the art cycle, which form the professional skills, abilities, psychotechnics of pedagogical activities of future professionals; study of the technology of selforganization of pedagogical activity, which is aimed at the creative development of the individual; education of motivation for constant personal and professional growth and self-improvement.

As a result of studying the discipline, students gained knowledge:

- on methodological principles, functions of art education, pedagogical conditions of the organization of studying disciplines of an art cycle;

- about the essence of pedagogical skill;

- on the pedagogical management of creative educational activities of students and on the specifics of their future profession; 
- on psychotechnics of pedagogical activity of specialists in music and choreographic education;

- on basic pedagogical concepts and their definitions;

- on basic scientific approaches, historical aspects of art education for the creative development of the individual;

- on features of the creative pedagogical process as a social phenomenon and of the subject of professional activity of a teacher of art education, its purpose, objectives, general laws and patterns;

- structural components, principles, forms, methods of organizing the creative pedagogical process and teaching disciplines in various arts, criteria for assessing the quality and effectiveness of educational and extracurricular work in the disciplines of the art cycle.

In the course of the research it was found that students learned:

- to observe and reveal features of realization of creative professional activity of the teacher in the course of studying of disciplines of an art cycle;

- apply theoretical knowledge of psychotechnics, pedagogical skills for analysis and classification of phenomena of pedagogical reality during pedagogical practice, implementation of educational projects;

- to characterize and substantiate the choice of forms and methods of organizing the creative pedagogical process depending on the purpose and main tasks of different types of art;

- to analyze their psychological, pedagogical, creative knowledge, skills, abilities in different micro-situations and the results of the creative pedagogical process in the course of studying the disciplines of the artistic cycle; generalize, interpret them;

- to reflect and evaluate their own abilities in mastering professional and pedagogical activities in the disciplines of the art cycle, in solving creative pedagogical problems;

- to plan the process of personal development and training of the profession of teacher of art education;

- independently organize their own educational work.

During the study of the modules «Art education as an object of scientific research», «Methodological principles of art education», «Art in sociocultural practice and human development», «Organizational and methodological principles of art education» students demonstrated the ability to freely, consciously operation of art-pedagogical thesaurus; to independent mastering of art and pedagogical material; to the application of modern methods and educational technologies to ensure the quality of pupils learning; to the development of educational and methodological materials for the activation of motivational, emotional and cognitive spheres of pupils 
personality; to investigation and productive transfer of modern innovative artistic and pedagogical achievements into own practice of children teaching.

During the implementation of the module «Pedagogical potential of art in the development of creative individuality of the future teacher of art disciplines», we stated that students were able at a high level to effectively and expediently realize the management functions of both teacher and organizer. (control, self-control, analysis, self-analysis, correction, forecasting, design of the following pedagogical actions in the process of organizational-methodical, educational-methodical, cultural-educational activity); apply methods of diagnosing and monitoring the creative achievements of pupils and their pedagogical correction; diagnose and adjust their own professional activity in terms of its artistic and pedagogical quality and effectiveness, evaluate the productivity of the methods used, develop ways to improve the quality of professional activity.

During the development of the module «Creative activities of teachers of art disciplines» students demonstrated ability to abstract thinking, analysis and synthesis of information; to search, process and analyze information from various sources; to work in a team, demonstrating the skills of interpersonal interaction.

At practical classes were considered the elements of theatrical pedagogy in the formation of pedagogical skills of the future teacher of art disciplines: the importance of theatrical art in the development of the individual's ability to reincarnate; the influence of theatrical pedagogy on the formation of creative individuality. Personality and professional self-development of the future teacher was promoted by creative pedagogy, namely, the subject and structure of creativity as bases of constructive pedagogical activity; genesis of creative pedagogical technologies.

During the competition of pedagogical skills, students mastered the pedagogical technique of the teacher. These were the means of verbal (speech communication (monologue, dialogue), speaking, listening, speech etiquette) and nonverbal communication (physiognomy, artifacts, kinexics (facial expressions), pantomime (gestures, postures, gait, actions); patting (touch, pressing, tapping, stroking), proxemics (organization of interpersonal space), prosody (timbre, tempo, pitch, of the voice volume, accents), extralinguistics (laughter, crying, pauses, coughing, yawning, taunting)).

Conclusion. Thus, we can state that the theoretical and practical achievements of the discipline «Pedagogy of Art» contributed to the improvement of psychological, pedagogical, creative knowledge, skills, abilities of future teachers in the study of disciplines of the art cycle and to the development (on this basis of individual programs of personal and 
professional growth), of forms of interaction of communication, creative approach to the professional skill.

\title{
References:
}

1. Dubina L.G. Theatrical pedagogy as a component of success of future primary school teachers//Problems of modern pedagogical education: a collection of articles. Kyiv: Pedagogical Press, 2006. Part 2. P. 65.

2. Lemesheva N.A., Kondratyuk N.V. Methods of teaching art: a textbook. Cherkasy. 2014. $124 \mathrm{~s}$.

3. Nichkalo N.G. Theoretical principles of formation and development of subdisciplines in pedagogy//Pedagogical skill as a system of professional and artistic competencies: a collection of materials of pedagogical and artistic readings / Ed. OHM. Father. Chernivtsi: Zelena Bukovyna, 2010. S. 23-31.

4. Rudnytska O.P. Pedagogy of art: searches and prospects//Professional education: pedagogy and psychology: Ukrainian-Polish yearbook. Kiev. Czestochowa. 2000. Vip. 2. P. 232-245.

5. Shevnyuk O. Art disciplines in the reform processes of European integration // Image of a modern teacher. 2006. № 5-6.

DOI https://doi.org/10.30525/978-9934-588-80-8-1.61

\section{РОЗВИТОК ПРОФЕСІЙНОЇ КОМПЕТЕНТНОСТІ ВЧИТЕЛЯ ФІЗИЧНОЇ КУЛЬТУРИ В УМОВАХ ДИСТАНЦІЙНОГО НАВЧАННЯ}

\author{
Онищук С. О. \\ викладач кафедри методики викладання $і$ змісту освіти \\ науково-методичної лабораторії виховання, \\ сочіальної і здоров'язбережувальної освіти \\ Комунальний заклад вищої освіти \\ «Одеська академія неперервної освіти Одеської обласної ради» \\ м. Одеса, Украӥна
}

Формування i розвиток професійної компетентності вчителя виступають сьогодні однією 3 центральних проблем у цілісній системі безперервної освіти. Ї̈̈ актуальність пояснюється необхідністю вирішення протиріччя, що виникло між новими вимогами, запропонованими до педагогічної діяльності вчителя як цілісної особистості, суб’єкта освітнього процесу, здатного до професійно-особистісного 